\title{
Greining og meðferð hárplokkunar- og húðkroppunaráráttu
}

Ívar Snorrason¹ doktorsnemi í sálfræði, Pröstur Björgvinsson² sálfræðingur

\section{ÁGRIP}

Hárplokkunarárátta (hair pulling disorder, trichotillomania) einkennist af síendurteknu hárplokki af höfði, augabrúnum eða annars staðar af líkamanum. Húokroppunarárátta (skin picking disorder, pathological skin picking) er náskyld hárplokkunaráráttu og einkennist af endurteknu kroppi á húð. Jafnvel pótt bæði húðkroppunar- og hárplokkunarárátta séu tiltölulega algengar og í mörgum tilvikum alvarleg vandamál er pekking fagfólks á peim oft afar takmörkuð. Í greininni lýsum við greiningarskilmerkjum og klínískum einkennum bessara kvilla og förum yfir helstu meðferðarúrræð og rannsóknir á árangri peirra. Niðurstöđur sýna að atferlismeðferð hefur ¡ðulega sýnt góðan árangur, SSRI-lyfjameðferð virðist ekki gera gagn en annars konar lyf (til dæmis $\mathrm{N}$-acetylcystín) lofa góðu.

Sálfræðideild háskólans í Wisconsin - Milwaukee, ${ }^{2}$ geðsviði McLeansjúkrahússins/Læknadeild Harvard-háskóla.

Fyrirspurni ivar Snorra

Greinin barst: sampykkt til birtingar: 3. febrúar 2012

\section{Inngangur}

Ebeneser Draummann ... var ... sköllóttur með peim hætti sem menn verða af svepp í hársverðinum ... Í staðinn fyrir augabrýn voru rauðir ílangir blettir sem virtust aumir, eins og brúnahárunum hefði verið kipt upp með rótum fyrir skemstu. Pó var ekki örgrant um að hann hefði ofurlítinn ójafnan skeggvöxt, rauðleitan, en pessa brodda nam hann á brott leynilega, ég held með einhverju öðru en rakhníf. (bls. 193) ${ }^{1}$

Hér lýsir Halldór Laxness persónu í Brekkukotsannál sem ætla má að hafi hárplokkunaráráttu (hair pulling disorder, trichotillomania). Pessi árátta einkennist af pví að fólk plokkar í sífellu hár af höfði, augabrúnum eða annars staðar af líkamanum. Peir sem pjást af pessari áráttu finna venjulega sterka löngun til að plokka hár og finna fyrir spennu eða fiðringi áður en plokkað er og spennulosun, sefjun eða ánægju pegar hár er dregið út. Hegðunin getur einnig verið sjálfvirk og ómeðvituð. Hárplokkunarárátta er oft prálátur ávani sem stendur fólki fyrir prifum. Margir eyða miklum tíma í athæfið og eins og lýsingin á Ebeneser Draummann ber með sér geta hlotist af pessu töluverð lýti, svo sem skallablettir á höfði eða hárlausar augabrúnir. ${ }^{2}$

Húðkroppunarárátta (skin picking disorder, pathological skin picking, psychogenic excoriation) er að öllum líkindum náskyld hárplokkunaráráttu. Pessar raskanir fara mun oftar saman en tilviljun ein getur skýrt og lýsa sér í öllum meginatriðum eins, að pví undanskildu að í einu tilvikinu er hárið plokkað en í hinu húðin kroppuð. ${ }^{3}$ Peir sem glíma við húðkroppunaráráttu kroppa venjulega minniháttar misfellur á húðinni, svo sem bólur, sár eða hrúður sem hefur myndast yfir sár frá fyrra kroppi. Algengt er að fólk með húðkroppunaráráttu hafi ánægju af hegðuninni og margir finna fyrir spennu eða fiðringi áður en kroppað er og spennulosun eða sefjun á meðan á kroppi stendur. Eins getur húðkropp verið sjálfvirkt og ómeðvitað líkt og hárplokk. Venjulega myndast sár eftir kroppið og í slæmum tilvikum veldur áráttan varanlegum áverkum á húð. ${ }^{4-7}$
Rannsóknir í Bandaríkjunum sýna að algengi hárplokkunaráráttu er um 0,6-2,5\% í hópi háskólanema ${ }^{8}$ en 3,9\% meðal skjólstæðinga á unglingageðdeild. ${ }^{9}$ Algengi húðkroppunaráráttu hefur reynst vera um 2,2\% meðal háskólanema ${ }^{10}$ og 1,4\% í almennu pýð $\mathrm{i}^{11}$ en $\%$ meðal peirra sem leita aðstoðar húðlækna ${ }^{12}$ og 11,8\% í hópi unglinga á unglingageðdeild. ${ }^{9}$ Tíðni hárplokkunar- og húðkroppunaráráttu hefur ekki verið rannsökuð vel hér á landi en könnun meðal háskólanema sýndi að 2,2\% höfðu húðkroppunaráráttu. ${ }^{13}$

Jafnvel pótt bæði húðkroppunar- og hárplokkunarárátta séu tiltölulega algengt og í mörgum tilvikum alvarlegt vandamál, sýna rannsóknir í Bandaríkjunum og Póllandi að pekking fagfólks á peim er yfirleitt afar takmörkuð., 14-16 Lítið hefur verið fjallað um pessar raskanir hér á landi ${ }^{4,5}$ og gera má ráð fyrir að pekking íslensks fagfólks á peim sé einnig takmörkuð. Markmiðið með pessari grein er að fræða heilbrigðisstarfsfólk um greiningu og meðferð á pessum kvillum. Lýst er klínískum einkennum og greiningarskilmerkjum, sagt frá helstu meðferðarúrræðum og farið yfir rannsóknir á árangri peirra.

\section{Greining og klínísk einkenni}

Greiningarskilmerki

Í töflu I má sjá greiningarskilmerki DSM-IV fyrir hárplokkunaráráttu. ${ }^{17}$ (Greiningarskilmerki ICD-10 eru ekki eins ítarleg en í öllum meginatriðum eins.) Húðkroppunarárátta hefur ekki enn hlotið sess í greiningarkerfum en í töflu II er uppástunga nefndar á vegum bandarísku geðlæknasamtakanna um greiningarskilmerki fyrir húðkroppunaráráttu í DSM-V. ${ }^{2}$

Töluverður hluti (um 20\%) peirra sem sannarlega pjást af óhóflegu hárplokki eða kroppi á húð segist sjaldan eða aldrei finna fyrir spennu eða ánægju pegar kroppað/plokkað er. ${ }^{3,6}$ Pess vegna hefur verið mælt með pví að hafa ekki greiningarskilmerki í DSM-V sem vísa 
Tafla I. Greiningarskilmerki fyrir hárplokkunaráráttu i DSM-IV.17

A. Endurtekið plokk á eigin hári sem veldur merkjanlegum hármissi.

B. Vaxandi spenna rétt áour en hár er dregið út eđa pegar reynt er að̃ standast löngun til að plokka hár.

C. Ánægja, fróun eða léttir pegar hár er dregið út.

D. Vandinn er ekki betur skýrður af annarri geðröskun eða líkamlegu vandamáli (t.d. húðvandamáli).

E. Vandinn veldur klínískt merkjanlegri vanlíðan eđa truflar viðkomandi í félagslífi, við störf eða á öðrum mikilvægum sviðum í lífinu.

Nefnd á vegum bandarísku geðlæknasamtakanna hefur mælt með pví að skilmerkin fyrir hárplokkunaráráttu í DSM-V geri ekki kröfu um merkjanlegan hármissi og ađ atriði B og C verði tekin út. ${ }^{2}$

til pessara einkenna. ${ }^{2}$ Einnig hefur verið mælt með pví að skilyrði um sjáanlegan hármissi verði tekið úr greiningarskilmerkjum DSM fyrir hárplokkunaráráttu vegna pess að hármissir margra sjúklinga er ekki pess eðlis að hann sé sjáanlegur. ${ }^{2}$ Fáein greiningarviðtöl hafa verið hönnuð til að meta greiningarskilmerki fyrir bæði hárplokkunar- og húðkroppunaráráttu en engar upplýsingar eru til um íslenskar pýðingar á peim. ${ }^{4}$

Kynjahlutfall, ferill og aldur við upphaf vandans

Konur eru í miklum meirihluta peirra sem leita sér hjálpar vegna hárplokkunar- eða húðkroppunaráráttu (um 75-93\% konur³). Pessi vandamál gera oftast fyrst vart við sig við upphaf unglingsáranna en geta pó komið upp á hvaða aldursskeiði sem er. Pví hefur verið haldið fram að hárplokkunarárátta í bernsku sé vægt afbrigði sem geti læknast af sjálfu sér. ${ }^{18}$ Hjá fullorðnum og unglingum eru petta hins vegar yfirleitt langvinn vandamál. ${ }^{2}$ Í flestum tilvikum kroppar/plokkar fólk daglega eða næstum daglega og löng einkennalaus tímabil eru sjaldgæf. Pó er áráttan venjulega misslæm eftir tímabilum og versnar oft pegar viðkomandi er undir álagi eða finnur fyrir streitu. ${ }^{3}$

\section{Lýsing á hegðun og áverkum}

Flestir plokka/kroppa í einrúmi í nokkurra mínútna lotum nokkrum sinnum yfir daginn eða í lengri lotum. Algengast er að athöfnin fari fram á baðherbergi (oft í tengslum við snyrtivenjur), svefnherbergi (til dæmis fyrir svefninn) eða við ýmiss konar kyrrsetu par sem hugurinn beinist að öðru en hegðuninni (til dæmis pegar fólk ekur bíl, les bók, talar í síma eða horfir á sjónvarp). Pá er hegðunin oft sjálfvirk og ómeðvituð., ${ }^{190}$

Flestir nota fingurna og draga út eitt hár af öðru eða kroppa sár með nöglunum en sumir nota einnig stundum áhöld, svo sem nálar eða flísatangir. Nýleg rannsókn sýndi að algengast var að fólk með hárplokkunaráráttu plokkaði hár af höfði (73\%), augabrúnum (56\%), augnhár (51\%), skapahár (50\%) og hár á fótleggjum (21\%). ${ }^{16}$ Fólk með húðkroppunaráráttu kroppar oftast andlitið, upphandleggi, fótleggi, hársvörð og fingur/naglabönd. ${ }^{5}$ Ýmsar venjur eru algengar bæði fyrir og eftir kroppið/plokkið. Til dæmis vilja sumir strjúka hárinu við varirnar eða velta dauðri húð milli fingranna. Ekki er óalgengt að fólk borði hárið eða húðina jafnóðum. ${ }^{3-5,7}$

Fólk með hárplokkunaráráttu er oft með skallabletti eða mismikinn hárvöxt á svæðum sem plokkuð eru. ${ }^{21}$ Fólk með húðkroppunaráráttu hefur jafnan áverka á stærð við bólur sem oft eru misgrónir, ýmist opin sár, hrúður eða blettir sem eru ljósari eða dekkri en húðin í kring. Margir sem kroppa húðina í andlitinu líta
Tafla II. Uppástunga nefndar á vegum bandarísku geđlæknasamtakanna um greiningarskilmerki fyrir húđkroppunaráráttu í $D S M-V^{2}$

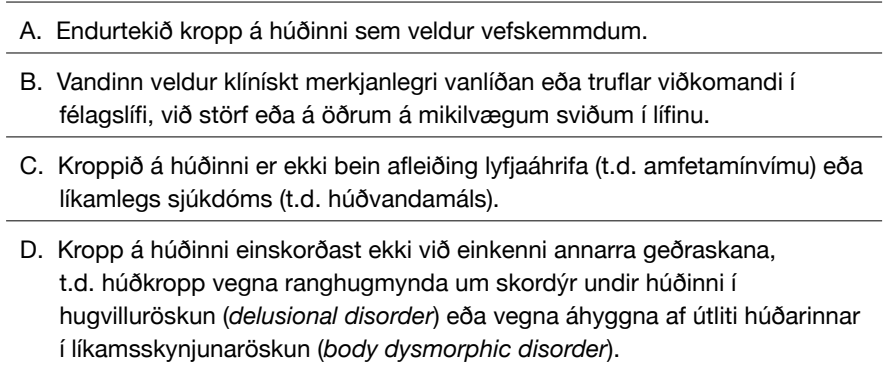

við fyrstu sýn út fyrir að glíma við bóluvandamál. ${ }^{22}$ Húðkroppunar- og hárplokkunarsjúklingar leggja venjulega mikið á sig til að leyna vandanum og fela til dæmis skallabletti með hárgreiðslum eða klútum eða hylja sár með farða eða klæðnaði.

\section{Tilfinningar í tengslum við hegðunina}

Eins og fram hefur komið er algengt að einstaklingar með hárplokkunar- eða húðkroppunaráráttu finni fyrir spennu eða löngun rétt áður en peir plokka/kroppa og ánægju eða spennulosun á meðan. En pað er einnig vert að hafa í huga að ýmsar aðrar tilfinningar tengjast plokki/kroppi. Til dæmis er algengt að fólk kroppi/ plokki pegar pað er kvíðið eða pegar pví leiðist. Rannsóknir sýna að bæði hárplokk ${ }^{23}$ og húðkropp ${ }^{6}$ dregur úr ýmsum ópægilegum tilfinningum, til dæmis kvíða eða leiða, sem bendir til pess að vandamálin viðhaldist með neikvæðri styrkingu.

Sumir fræðimenn hafa gert greinarmun á tvenns konar hárplokkunar- og húðkroppunaráráttu. ${ }^{19,}{ }^{20}$ Annars vegar afbrigði par sem viðkomandi kroppar/plokkar sjálfvirkt og ómeðvitað (automatic pulling/picking) og hins vegar par sem viðkomandi kroppar/ plokkar pegar hann finnur fyrir löngun, spennu eða slæmum tilfinningum og er með hugann við verkið á meðan (focused pulling/picking). Flestir sjúklingar kannast við hvort tveggja, bó í mismiklum mæli. Pví hefur verið haldið fram að ólík meðferð kunni að henta pessum tveimur afbrigðum en rannsóknir eiga enn eftir að skera úr um pað. ${ }^{19,20}$

\section{Tengsl við aðrar geðraskanir}

Stór hluti peirra sem leitar sér hjálpar vegna húðkroppunar- eða hárplokkunaráráttu glímir við aðrar geðraskanir. Rannsóknir sýna að um tveir priðju hlutar hafa greinst með einhverja kvíðaröskun og rúmlega helmingur hefur greinst með punglyndi. ${ }^{3}$ Líkamsskynjunarröskun (body dysmorphic disorder) er einnig algeng meðal húðkroppunarsjúklinga (um 5-30\% lífstíðaralgengi),,$^{3-5}$ og pað getur verið gagnlegt að kanna hvort áhyggjur af útliti húðarinnar liggi að baki hegðuninni. Að auki er algengt, eins og fram hefur komið, að hárplokkunarárátta og húðkroppunarárátta fari saman. ${ }^{3}$ Báðar pessar raskanir tengjast auk pess töluvert við ýmiss konar ávanahegðun, svo sem að naga neglur óhóflega eða naga innan úr vörum. ${ }^{5}$ Pví getur verið gagnlegt að spyrja um alla slíka hegðun ef einhver líkamsmiðuð árátta er til staðar. Persónuleikaraskanir eru nokkuð algengar hjá peim sem sækja meðferð en pað er mikilvægt að gera greinarmun á hárplokki og húðkroppi og sjálfskaðandi hegðun (til dæmis að skera eða brenna húðina) sem oft eru dæmi um hjá fólki með persónuleikaraskanir.. ${ }^{24}$ 
Tafla III. Niðurstöður samanburðarrannsókna á lyfjameðferð fyrir hárplokkunaráráttu.

\begin{tabular}{|c|c|c|c|c|}
\hline & Rannsóknarsnið & Meðferð/Pátttakendur & Mat & Niðurstaða \\
\hline \multicolumn{5}{|l|}{ Serótónínlyf } \\
\hline Christenson ${ }^{25}$ & $\begin{array}{c}\text { Tvíblind samanburðarrannsókn } \\
\text { par sem hvor meðferð var gefin } \\
\text { báðum hópum (cross over } \\
\text { design). }\end{array}$ & $\begin{array}{c}16 \text { hárplokkunarsjúklingar fengu } 6 \text { vikna } \\
\text { flúoxetínmeðferð (meðaldagskammtur } 77 \text { mg) } \\
\text { og } 6 \text { vikna lyfleysumeðferð. Fimm vikna biðtími } \\
\text { milli meðferða. }\end{array}$ & Sjálfsmat & $\begin{array}{l}\text { Ekki marktækur munur á flúoxetín- } \\
\text { og lyfleysumeðferð. }\end{array}$ \\
\hline Streichenwein ${ }^{26}$ & $\begin{array}{c}\text { Tvíblind samanburðarrannsókn } \\
\text { par sem hvor meðferð var gefin } \\
\text { báðum hópum (cross over } \\
\text { design). }\end{array}$ & $\begin{array}{c}16 \text { hárplokkunarsjúklingar fengu } 12 \text { vikna } \\
\text { flúoxetínmeðferð (meðaldagsskammtur } 78,8 \\
\text { mg) og } 12 \text { vikna lyfleysumeðferð. Tólf vikna } \\
\text { biðtími milli meðferða. }\end{array}$ & Sjálfsmat & $\begin{array}{l}\text { Ekki marktækur munur á flúoxetín- } \\
\text { og lyfleysumeðferð. }\end{array}$ \\
\hline van Minnen ${ }^{27}$ & Tvíblind samanburðarrannsókn & $\begin{array}{l}40 \text { hárplokkunarsjúklingar fengu annaðhvort } 12 \\
\text { vikna flúoxetínmeðferð (meðaldagsskammtur } \\
60 \text { mg), } 12 \text { vikna HR-meðferð ( } 6 \text { meðferðartímar } \\
\text { aðra hverja viku) eða voru } 12 \text { vikur á biðlista. }\end{array}$ & Sjálfsmatskvarði & $\begin{array}{l}\text { Ekki marktækur munur á } \\
\text { flúoxetínmeðferð og biðlista. } \\
\text { (HR-meðferð gerði meira gagn en } \\
\text { flúoxetín og biðlisti). }\end{array}$ \\
\hline Dougherty ${ }^{28}$ & Tvíblind samanburðarrannsókn & $\begin{array}{l}13 \text { hárplokkunarsjúklingar fengu annaðhvort } 12 \\
\text { vikna sertralínmeðferð (dagsskammtar á bilinu } \\
50 \text { til } 200 \text { mg) eða } 12 \text { vikna lyfleysumeðferð. }\end{array}$ & $\begin{array}{l}\text { Sjálfsmatskvarðar } \\
\text { og hálfstaðlað viðtal }\end{array}$ & $\begin{array}{l}\text { Ekki marktækur munur á sertralín } \\
\text { og lyfleysu. }\end{array}$ \\
\hline Swedo ${ }^{31}$ & $\begin{array}{l}\text { Tvíblind samanburðarrannsókn } \\
\text { par sem hvor meðferð var gefin } \\
\text { báðum hópum (cross over } \\
\text { design). }\end{array}$ & $\begin{array}{c}13 \text { hárplokkunarsjúklingar fengu } 10 \text { vikna } \\
\text { klómipramín-meðferð (meðaldagskammtur } \\
\text { 180,8 mg) og } 10 \text { vikna desipramín-meðferð } \\
\text { (meðaldagsskammtur } 173,1 \text { mg). Enginn biðtími } \\
\text { milli meðferða. }\end{array}$ & Hálfstaðlað viðtal & $\begin{array}{l}\text { Klómipramín-meðferð gerði } \\
\text { marktækt meira gagn en } \\
\text { desipramín-meðferð. }\end{array}$ \\
\hline Ninan $^{32}$ & Tvíblind samanburðarrannsókn & $\begin{array}{l}16 \text { hárplokkunarsjúklingar fengu } \\
\text { annaðhvort } 9 \text { vikna klómipramín-meðferð } \\
\text { (meðaldagsskammtur } 116,7 \text { mg), } 9 \text { vikulega HR } \\
\text { meðferðartíma eða } 9 \text { vikna lyfleysumeðferð. }\end{array}$ & Hálfstaðlað viðtal & $\begin{array}{l}\text { Ekki marktækur munur á } \\
\text { klómipramín og lyfleysu. } \\
\text { (HR-meðferð gerði meira gagn en } \\
\text { lyfleysa og klómipramín.) }\end{array}$ \\
\hline Ninan $^{35}$ & Tvíblind samanburðarrannsókn & $\begin{array}{c}8 \text { hárplokkunarsjúklingar sem höfðu svarað } \\
12 \text { vikna venlafaxínmeðferð fengu annaðhvort } \\
\text { áframhaldandi } 12 \text { vikna venlafaxín-meðferð } \\
\text { (meðaldagsskammtur } 322.5 \mathrm{mg} \text { ) eða } 12 \text { vikna } \\
\text { lyfleysumeðferð. }\end{array}$ & Hálfstaðlað viðtal & $\begin{array}{l}\text { Enginn munur á áframhaldandi } \\
\text { venlafaxín- og lyfleysumeðferð. }\end{array}$ \\
\hline \multicolumn{5}{|l|}{ Önnur lyf } \\
\hline Grant $^{36}$ & Tvíblind samanburðarrannsókn & $\begin{array}{c}50 \text { hárplokkunarsjúklingar fengu annaðhvort } 12 \\
\text { vikna N-acetylcystín-meðferð (dagsskammtur } \\
\text { á bilinu 1200-2400 mg) eða } 12 \text { vikna } \\
\text { lyfleysumeðferð. }\end{array}$ & $\begin{array}{l}\text { Spurningalisti og } \\
\text { hálfstaðlað viðtal }\end{array}$ & $\begin{array}{l}55 \% \text { af peim sem fengu } \\
\mathrm{N} \text {-acetylcystínmeðferð og } 16 \% \\
\text { af peim sem fengu lyfleysu sýndu } \\
\text { mikinn eða mjög mikinn bata. }\end{array}$ \\
\hline van Ameringen ${ }^{37}$ & Tvíblind samanburðarrannsókn & $\begin{array}{c}25 \text { hárplokkunarsjúklingar fengu annaðhvort } 12 \\
\text { vikna ólanzapínmeðferð (meðaldagsskammtur } \\
\text { í lok meðferðar var 10,8 mg) eða } 12 \text { vikna } \\
\text { lyfleysumeðferð. }\end{array}$ & Hálfstaðlað viðtal & $\begin{array}{l}85 \% \text { af peim sem fengu ólanzapín } \\
\text { og } 17 \% \text { af peim sem fengu lyfleysu } \\
\text { töldust hafa svarað meðferðinni. }\end{array}$ \\
\hline
\end{tabular}

Vanliððan

Fagfólk ætti ekki að vanmeta pað hversu mjög fólk getur verið bjakað af hárplokkunar- og húðkroppunaráráttu. Margir sjúklingar lýsa slæmri vanlíðan vegna pessara vandamála og lítið sjálfsálit, óángja með útlitið, vonleysi og sjálfsvígshugsanir eru algengir fylgifiskar. ${ }^{24}$ Einnig er algengt að fólk einangrist félagslega og flosni upp úr vinnu. Loks fylgja pessu ýmis læknisfræðileg vandamál, svo sem sýkingar í húð, sinaskeiðabólga og stífla í meltingarvegi hjá peim sem borða hárin. Stífla í meltingarvegi af völdum hárbolta getur verið lífshættuleg og pví er ráð að vera vakandi fyrir peim vanda, jafnvel pótt hann sé ekki algengur. ${ }^{2}$

\section{Lyfjameðferd}

Ýmis lyf hafa verið reynd í meðferð við húðkroppunar- og hárplokkunaráráttu. Hér verður farið yfir rannsóknir á lyfjameðferð fullorðinna og fjallað nánast eingöngu um lyf sem hafa verið prófuð í að minnsta kosti einni samanburðarrannsókn (tafla III og IV).

\section{Serótónínlyf við hárplokkunaráráttu \\ SSRI-lyf (Serotonin specific reuptake inhibitors)}

Fjórar fámennar samanburðarrannsóknir hafa verið gerðar á gagnsemi SSRI-lyfja í meðferð við hárplokkunaráráttu (fjöldi í meðferðarhóp á bilinu 9 til 16). Í premur peirra var pátttakendum gefið flúoxetín (meðaldagskammtur $60-78 \mathrm{mg}$ ) ${ }^{25-27}$ og í einni var sertralín gefið (hámarksdagskammtur $200 \mathrm{mg}$ ). ${ }^{28}$ Niðurstöður í öllum rannsóknunum sýndu að SSRI-lyf gerðu ekki meira gagn en lyfleysa eða vera á biðlista. Allsherjargreining (meta analysis) á pessum rannsóknum benti einnig til pess að SSRI-lyf beri ekki árangur umfram lyfleysuáhrif (áhrifastærð = -0,02; 95\% öryggisbil frá -0,32 til 0,35). ${ }^{29}$ Í fáeinum tilfellalýsingum og rannsóknum án 
Tafla IV. Niðurstöður samanburðarrannsókna á lyfjameðferð fyrir húðkroppunaráráttu.

\begin{tabular}{|c|c|c|c|c|}
\hline & Rannsóknarsnið & Meðferð/pátttakendur & Mat & Niðurstaða \\
\hline \multicolumn{5}{|l|}{ SSRI-lyf } \\
\hline Simeon ${ }^{41}$ & $\begin{array}{l}\text { Tvíblind } \\
\text { samanburðar- } \\
\text { rannsókn }\end{array}$ & $\begin{array}{c}17 \text { húđkroppunarsjúklingar fengu annaðhvort } 10 \\
\text { vikna flúoxetínmeðferð (dagsskammtur allt að } 80 \\
\text { mg) eða } 10 \text { vikna lyfleysumeðferð. }\end{array}$ & Spurningalistar & $\begin{array}{l}\text { Flúoxetínmeðferð gerði meira gagn en lyfleysa } \\
\text { samkvæmt einum af premur spurningalistum. }\end{array}$ \\
\hline Bloch $^{40}$ & $\begin{array}{l}\text { Tvíblind } \\
\text { samanburðar- } \\
\text { rannsókn }\end{array}$ & $\begin{array}{l}8 \text { húðkroppunarsjúklingar sem höfðu svarað } \\
\text { flúoxetínmeðferð fengu annaðhvort áframhaldandi } \\
6 \text { vikna flúoxetínmeðferð (dagsskammtur allt að } 60 \\
\text { mg) eða } 6 \text { vikna lyfleysumeðferð. }\end{array}$ & $\begin{array}{l}\text { Spurningalisti og } \\
\text { hálfstaðlað viðtal }\end{array}$ & $\begin{array}{l}\text { Peir sem fengu áframhaldandi flúoxetínmeðferð } \\
\text { héldu batanum, en ekki peir sem fengu } \\
\text { lyfleysumeðferð. }\end{array}$ \\
\hline Arbabi ${ }^{42}$ & $\begin{array}{l}\text { Tvíblind } \\
\text { samanburðar- } \\
\text { rannsókn }\end{array}$ & $\begin{array}{l}45 \text { húđkroppunarsjúklingar fengu annaðhvort } \\
\text { fjögurra vikna cítalópram-meðferð (dagsskammtur } \\
20 \text { mg) eða fjögurra vikna lyfleysumeðferð. }\end{array}$ & Sjálfsmatskvarði & $\begin{array}{l}\text { Ekki marktækur munur á cítalópram- og } \\
\text { lyfleysumeðferð. }\end{array}$ \\
\hline \multicolumn{5}{|l|}{ Önnur lyf } \\
\hline Grant $^{44}$ & $\begin{array}{l}\text { Tvíblind } \\
\text { samanburðar- } \\
\text { rannsókn }\end{array}$ & $\begin{array}{l}32 \text { húđkroppunarsjúklingar fengu annaðhvort } 12 \\
\text { vikna lamótrigínmeðferð (dagsskammtar } 12.5 \text { til } \\
300 \text { mg) eða } 12 \text { vikna lyfleysumeðferð. }\end{array}$ & Hálfstaðlað viðtal & $\begin{array}{l}\text { Ekki marktækur munur á lamótrigín- og } \\
\text { lyfleysumeðferð. En pátttendur sem skoruðu lágt á } \\
\text { taugasálfræðiprófi svöruðu lamótrigín-meðferðinni. }\end{array}$ \\
\hline
\end{tabular}

samanburðarhóps hefur pó verið greint frá ágætum árangri pessara lyfja. Hins vegar virðist algengt í pessum tilvikum að lyfin hætti að virka eftir nokkra mánuði prátt fyrir áframhaldandi lyfjameðferð. ${ }^{30}$

\section{Klómipramín}

Áhrif klómipramíns í meðferð við hárplokkunaráráttu hafa verið könnuð í tveimur samanburðarrannsóknum. Í annarri rannsókninni sem náði til 13 sjúklinga kom í ljós að 5 vikna klómipramínmeðferð (meðaldagskammtur $180 \mathrm{mg}$ ) gerði meira gagn en jafnlöng desipramínmeðferð. ${ }^{31}$ Í hinni reyndist 9 vikna klómipramínmeðferð ( $n=4$, meðaldagsskammtur $116 \mathrm{mg}$ ) árangursríkari en jafnlöng lyfleysumeðferð. ${ }^{32}$ Í síðarnefndu rannsókninni var munurinn á bata hópanna ekki tölfræðilega marktækur en allsherjargreining á pessum tveimur rannsóknum benti til pess að lyfið geri marktækt meira gagn en lyfleysa eða desipramín (áhrifastærð = -0,68; 95\% öryggisbil frá -1,28 til -0,07). ${ }^{29}$ Niðurstöður varðandi langtímaáhrif klómipramíns eru misvísandi og sumar rannsóknir benda til pess að lyfin hætti að virka eftir nokkra mánuði. ${ }^{30,33}$ Að auki virðist fólk með hárplokkunaráráttu pola klómipramín illa og almennt verr en áráttu- og práhyggjusjúklingar. ${ }^{32}$

\section{Venlafaxín}

Ninan og félagar gáfu 20 hárplokkunarsjúklingum venlafaxín (meðaldagskammtur $322,5 \mathrm{mg}$ ) í allt að 12 vikur og eftir meðferð taldist rétt rúmur helmingur ( $\mathrm{n}=11,55 \%)$ hafa svarað lyfjunum pegar miðað var við 50\% minnkun einkenna. ${ }^{34}$ Í kjölfarið gerðu höfundar tvíblinda samanburðarrannsókn par sem 8 af peim sem svöruðu meðferð var annaðhvort gefið lyfið áfram eða lyfleysa. Niðurstöður sýndu að öllum sjúklingunum (nema einum sem fékk lyfleysu) hrakaði og fóru í sama farið innan 24 vikna prátt fyrir áframhaldandi meðferð. ${ }^{35}$

\section{Önnur lyf við hárplokkunaráráttu}

Stór tvíblind samanburðarrannsókn $(n=50)$ leiddi í ljós að rétt rúmum helmingi (55\%) hárplokkunarsjúklingum sem fengu 12 vikna N-acetylcystínmeðferð (dagsskammtur á bilinu 1200-2400 mg) taldist hafa batnað verulega (mikill eða mjög mikill bati) en aðeins lítill hluti (16\%) skjólstæðinga sem fékk jafnlanga lyfleysumeðferð greindi frá sambærilegum bata. ${ }^{36}$ Pátttakendur í rannsókninni poldu lyfið vel og pví lofa pessar niðurstöður góðu. Pó er enn ekki vitað hvort lyfið ber árangur til lengri tíma.

van Ameringen og félagar ${ }^{37}$ könnuðu árangur ólanzapíns í 12 vikna tvíblindri samanburðarrannsókn og komust að pví að 11 af 13 (85\%) einstaklingum sem gengust undir meðferðina (sveigjanlegir og stigvaxandi dagsskammtar, minnst $2,5 \mathrm{mg}$ og allt að 20 mg í lok rannsóknar) töldust hafa náð markverðum bata. Einungis tveir af 12 (17\%) í samanburðarhópnum fengu jafn mikinn bata. Stór hluti pátttakenda sem fékk lyfið greindi frá aukaverkunum en enginn hætti meðferð vegna peirra. Árangur ólanzapíns hefur einnig komið í ljós í tilfellalýsingum og rannsóknum án samanburðar ${ }^{38}$ en lítið er vitað um langtímaáhrif pessara lyfja.

Ýmis önnur lyf hafa verið reynd gegn hárplokkunaráráttu, par á meðal litíum, quetiapín, inosítol og amitriptylín. Auk pess hafa ýmis lyf verið reynd sem viðbótarmeðferð við serótónínlyfjameðferð. Má par nefna ólanzapín, risperídón, halóperídól, naltrexón og pimozide.$^{39}$ Rannsóknir á pessum lyfjum eða lyfjablöndum hafa enn sem komið er einskorðast við tilfellalýsingar eða fámennar samanburðarlausar rannsóknir og pví vandasamt að draga ályktanir af peim. Einnig hafa komið fram vísbendingar um að SSRI-lyf og atferlismeðferð saman beri meiri árangur en hvor meðferðin fyrir sig og vert að kanna pað betur. ${ }^{28}$

\section{SSRI-lyf við húðkroppunaráráttu}

Prjár samanburðarrannsóknir hafa verið gerðar á árangri SSRIlyfja gegn húðkroppunaráráttu (tafla IV). Í rannsókn Bloch og félaga $^{40}$ fengu 8 af 16 sjúklingum (50\%) markverðan bata eftir 10 vikna flúoxetínmeðferð (meðaldagsskammtur $41 \mathrm{mg}$ ). Peim var síðan skipt tilviljanakennt í tvo jafnstóra hópa og annaðhvort gefið lyfið áfram eða lyfleysa. Niðurstöður sýndu að allir pátttakendur í lyfleysuhópnum fóru í sama farið á innan við 6 vikum en batinn hélst hjá peim sem fengu lyfið áfram. Simeon og félagar ${ }^{41}$ fundu hins vegar aðeins mun á árangri milli lyfleysu- og flúoxetínmeðferðar á einni af premur mælingum og stærsta samanburðarrann- 
Tafla V. Niðurstöður samanburðarrannsókna á atferlismeðferð (habit reversal, HR) fyrir hárplokkunar- og húðkroppunaráráttu.

\begin{tabular}{|c|c|c|c|c|}
\hline & Rannsóknarsnið & Meðferð/pátttakendur & Mat & Niðurstaða \\
\hline \multicolumn{5}{|c|}{ Hárplokkunarárátta } \\
\hline Azrin ${ }^{52}$ & Samanburðarrannsókn & $\begin{array}{c}34 \text { hárplokkunarsjúklingar fengu } \\
\text { annaðhvort tvo HR-meðferðartíma eða } \\
\text { tvo meðferðartíma af ofpjálfun (massed } \\
\text { negative practice). }\end{array}$ & Sjálfsmat & $\begin{array}{c}\text { Tíðni hárplokks lækkaði 90\% } \\
\text { í HR-hópnum, en } 50 \% \text { í } \\
\text { ofpjálfunarhópnum. }\end{array}$ \\
\hline Ninan $^{32}$ & Samanburðarrannsókn & $\begin{array}{l}16 \text { hárplokkunarsjúklingar fengu annaðhvort } \\
9 \text { vikulega meðferðartíma (HR + hugræn } \\
\text { meðferð), } 9 \text { vikna klómipramín-meðferð eða } \\
\text { fengu } 9 \text { vikna lyfleysumeðferð. }\end{array}$ & Hálfstaðlað viðtal & $\begin{array}{c}\mathrm{HR}+\text { hugræn meðferð gerði marktækt } \\
\text { meira gagn en klómipramín og } \\
\text { lyfleysa. }\end{array}$ \\
\hline van Minnan ${ }^{27}$ & Samanburðarrannsókn & $\begin{array}{c}40 \text { hárplokkunarsjúklingar fengu annaðhvort } \\
6 \text { HR-meðferðartíma aðra hverja viku, } 12 \\
\text { vikna flúoxetínmeðferð eða voru } 12 \text { vikur á } \\
\text { biðlista. }\end{array}$ & Sjálfsmatskvarði & $\begin{array}{l}\text { HR gerði marktækt meira gagn ( } 64 \% \\
\text { fengu verulegan bata) en flúoxetín } \\
\text { (9\% fengu verulegan bata) og biðlisti } \\
\text { (20\% fengu verulegan bata). }\end{array}$ \\
\hline Woods $^{51}$ & Samanburðarrannsókn & $\begin{array}{l}25 \text { hárplokkunarsjúklingar fengu } \\
\text { annaðhvort } 10 \text { vikulega hópmeðferðartíma } \\
\text { af HR + ACT eða voru } 10 \text { vikur á biðlista. }\end{array}$ & Sjálfsmatskvarði & $\begin{array}{c}\text { HR + ACT gerði marktækt meira gagn } \\
\text { en að vera á biðlista. }\end{array}$ \\
\hline Diefenbach ${ }^{53}$ & Samanburðarrannsókn & $\begin{array}{l}24 \text { hárplokkunarsjúklingar fengu annaðhvort } \\
8 \text { vikulega HR-hópmeðferðatíma eða } 8 \\
\text { vikulega meðferðartíma sem samanstóðu af } \\
\text { fræðslu og félagslegum stuðningi. }\end{array}$ & $\begin{array}{l}\text { Sjálfsmatskvarði og } \\
\text { hálfstaðlað viðtal. }\end{array}$ & $\begin{array}{l}\text { HR gerði marktækt meira gagn en } \\
\text { fræðsla/félagslegur stuðningur. }\end{array}$ \\
\hline \multicolumn{5}{|c|}{ Húðkroppunarárátta } \\
\hline Teng $^{55}$ & Samanburðarrannsókn & $\begin{array}{l}19 \text { húðkroppunarsjúklingar fengu } \\
\text { annaðhvort prjá HR-meðferðartíma eða voru } \\
\text { fjórar vikur á biðlista. }\end{array}$ & $\begin{array}{l}\text { Sjálfsmatskvarði og } \\
\text { óháð mat á myndum } \\
\text { af áverkum á húð. }\end{array}$ & $\begin{array}{c}\text { HR gerði marktækt meira gagn en að } \\
\text { vera á biðlista. }\end{array}$ \\
\hline Schuck $^{56}$ & Samanburðarrannsókn & $\begin{array}{l}34 \text { húðkroppunarsjúklingar fengu } \\
\text { annaðhvort HR + hugræna meðferð (fjórir } \\
\text { meðferðartímar) eða voru } 5 \text { vikur á biðlista. }\end{array}$ & $\begin{array}{l}\text { Sjálfsmatskvarðar og } \\
\text { óháð mat á myndum } \\
\text { af áverkum á húð. }\end{array}$ & $\begin{array}{l}\text { HR gerði marktækt meira gagn en að } \\
\text { vera á biðlista. }\end{array}$ \\
\hline
\end{tabular}

sókn sem gerð hefur verið hingað til leiddi ekki í ljós neinn mun á lyfleysu (n=22) og cítalópram (n=23) pegar litið var til alvarleika húðkroppunaráráttu eftir fjögurra vikna meðferð. ${ }^{42}$ Einnig er lítið vitað um langtímaáhrif pessara lyfja í meðferð við húðkroppunaráráttu. Pegar á heildina er litið benda rannsóknir til pess að líklegt sé að SSRI-lyf geri takmarkað gagn við húðkroppunaráráttu.

\section{Önnur lyf við húðkroppunaráráttu}

Grant, Odlaug og Kim greindu frá pví að 16 af 24 (66,7\%) húðkroppunarsjúklingum sem gengust undir 12 vikna lamótrigínmeðferð (meðaldagskammtur $=200 \mathrm{mg}$ ) töldust hafa náð miklum eða mjög miklum bata eftir meðferð. ${ }^{43}$ Tvíblind samanburðarrannsókn eftir sömu höfunda leiddi í ljós að lyfið gerði ekki marktækt meira gagn en lyfleysa par sem 43,8\% í lamótrigínhóp og 31,3\% 1́ lyfleysuhóp töldust hafa náð markverðum bata. ${ }^{44}$ Hins vegar kom í ljós að pátttakendur sem stóðu sig illa á taugasálfræðiprófi sem mælir sveigjanleika í hugsun (set shifting task) svöruðu meðferðinni. Pannig er hugsanlegt að sumir húðkroppunarsjúklingar hafi gagn af lamótrigínmeðferð. Ýmis önnur lyf hafa verið reynd gegn húðkroppunaráráttu en engar samanburðarrannsóknir hafa verið gerðar á peim. Hér má nefna N-acetylcystín, ${ }^{45}$ ólanzapín, pimozíd, doxepín, naltrexón og inosítól í bland við cítalópram. ${ }^{46}$

\section{Sálfræðimeðferð}

Margs konar sálfræðimeðferð hefur verið beitt gegn hárplokkunar- og húðkroppunaráráttu. Má til dæmis nefna dáleiðslu, sálgreiningu, hugræna meðferð og atferlismeðferð ýmiss konar. Aðeins ein tegund sálfræðimeðferðar hefur verið athuguð í samanburðarrannsóknum. Рað er atferlismeðferð sem kallast á ensku habit reversal (HR). Petta er einföld en árangursrík meðferð sem samanstendur af premur meginpáttum. ${ }^{47}$ Fyrst er skjólstæðingi kennt að átta sig á pví pegar hann er að fara að plokka eða kroppa (awareness training). Pví næst er hann pjálfaður í tiltekinni hreyfingu eða athæfi í staðinn fyrir að kroppa/plokka (competing response training), til dæmis að kreppa hnefann eða kreista bolta í hvert skipti sem hann finnur fyrir löngun til að plokka hár. Priðji pátturinn er stuðningur frá einhverjum nákomnum (social support). Pá er til dæmis foreldri kennt að hrósa barni ef pað gerir hreyfinguna sem pað á að gera í staðinn fyrir að plokka/kroppa. Venjulega er áreitisstjórnun (stimulus control) notuð samhliða HR en hún snýst um að útrýma eða stjórna áreitum í umhverfinu sem kalla fram hegðunina. ${ }^{48}$ Pá er til dæmis skjólstæðingi sem venjulega kroppar húðina pegar hann er að skoða sig í spegli ráðlagt að breiða yfir spegla í íbúðinni. Loks ber að nefna að í ljósi rannsókna sem sýna að margir sjúklingar kroppa eða plokka til pess að takast á við neikvæðar tilfinningar hafa menn í auknum mæli blandað við HR sálfræðimeðferð sem beinist að neikvæðum tilfinningum. Hér má nefna hugræna meðferð (cognitive therapy) ${ }^{32}$, díalektíska atferlismeðferð (dialectical behavior therapy) ${ }^{49}$ og meðferð sem kallast á ensku acceptance and commitment therapy (ACT). ${ }^{50,51}$

\section{Árangur HR við hárplokkunaráráttu}

Fimm rannsóknir hafa verið gerðar par sem sálfræðimeðferð sem felur í sér HR (fjöldi í meðferðarhóp á bilinu 5-19) var borin saman við biðlista eða samanburðarmeðferð (svokallaða ofpjálfun (massed negative practice), fræðslu/félagslegan stuðning, klómipramín eða SSRI-lyf), sjá töflu V. 27, 32, 51-53 Í tveimur pessara rannsókna var HR veitt með annarri meðferð, annars vegar hugrænni meðferð ${ }^{32}$ og hins vegar ACT. ${ }^{51}$ Í öllum pessum 5 rannsóknum kom í ljós 
að meira en $60 \%$ pátttakenda sem fengu HR sýndu markverðan bata (skilgreint með mismunandi hætti) og í öllum tilvikum var árangurinn meiri en í samanburðarhópi. Enn fremur sýndi allsherjargreining á niðurstöðum priggja pessara rannsókna ${ }^{27,32,51}$ að meðferðin ber árangur (áhrifastærð = -1,14; 95\% öryggisbil frá -1,89 til -0,38) og gerir meira gagn en lyfleysa, SSRI-lyf eða klómipramín. ${ }^{29}$ Pá leiddi rannsókn Diefenbach og félaga ${ }^{53} 1$ ljós að 8 af 12 sjúklingum (66,7\%) sem fengu HR-hópmeðferð sýndu „mikinn“ eða „mjög mikinn“ bata en einungis prír af 12 (25\%) pátttakendum fengu jafn mikinn bata eftir samanburðarhópmeðferð sem fól í sér fræðslu og félagslegan stuðning. Pó bentu höfundar á að hópmeðferð virðist bera minni árangur en einstaklingsmeðferð, sérstaklega pegar litið er til pess að mun fleiri hætta alveg að plokka í einstaklingsmeðferð.

Misvísandi niðurstöður hafa fengist varðandi langtímaáhrif HR. Á áttunda áratugnum greindu Azrin og félagar ${ }^{52}$ frá góðum árangri tveimur árum eftir meðferð en flestar rannsóknir síðan pá hafa sýnt að hrösun er algeng pegar einkenni eru metin meira en ári eftir að meðferð lýkur. ${ }^{54}$ Svo virðist sem skjólstæðingar sem ná sér alveg í meðferðinni (hætta alveg að plokka), séu líklegri til að viðhalda batanum til lengri tíma en peir sem hætta ekki alveg. ${ }^{54}$ Pess vegna hefur verið mælt með pví að halda áfram meðferð pangað til hegðunin er alveg hætt, ef kostur er á. Einnig hefur verið bent á að ástæðan fyrir hrösun er oft sú að viðkomandi hættir að beita aðferðunum sem kenndar voru í meðferðinni. Pví getur verið gagnlegt að bjóða upp á upprifjunarmeðferðartíma (booster sessions) annað slagið eftir að meðferð lýkur. Annað sem skiptir máli í árangri HR er áhugi skjólstæðingsins á bata og meðferðarheldni hans ${ }^{51}$ enda krefst meðferðin pess að skjólstæðingurinn sinni heimavinnu og tileinki sér aðferðirnar sem kenndar eru í meðferðartímum.

\section{Árangur HR við húðkroppunaráráttu}

Í tveimur samanburðarrannsóknum hefur árangur HR við húðkroppunaráráttu verið kannaður (tafla V). Teng, Woods og Twohig ${ }^{55}$ greindu frá pví að HR (prír meðferðartímar; $n=8$ ) gerði marktækt meira gagn en vera á biðlista $(n=8)$ og árangurinn hélst að mestu leyti premur mánuðum síðar. Svipuð rannsókn ${ }^{56}$ leiddi í ljós að HR í bland við hugræna meðferð (fjórir meðferðartímar; $\mathrm{n}=17)$ gerði meira gagn en vera á biðlista $(\mathrm{n}=17)$ og batinn hélst að mestu leyti tveimur mánuðum síðar. Fjöldi tilfellalýsinga bendir í sömu átt. ${ }^{57}$ Einnig hafa komið fram vísbendingar um að ACT $^{58}$ og hugræn meðferð ${ }^{57}$ einar og sér dragi úr húðkroppunaráráttu en petta parf að kanna betur í samanburðarrannsóknum.

\section{Umræða}

Húðkroppunar- og hárplokkunarárátta eru tiltölulega algeng vandamál en pau eru lítið pekkt, bæði meðal fagfólks og almenn- ings. Margir sem glíma við pau veigra sér við að leita sér hjálpar vegna feimni við að segja frá hegðuninni eða vegna pess að peir vita ekki að petta eru viðurkenndar raskanir sem hægt er að fá hjálp við. Að sama skapi sýna rannsóknir að heilbrigðisstarfsfólk pekkir oft ekki pessi vandamál eða misskilur ýmislegt um orsakir, einkenni eða meðferð við peim. ${ }^{14,15}$ Pví fylgir gjarnan mikil skömm að glíma við pessa kvilla og pví parf að sýna nærgætni pegar spurt er um pá. Einnig er vert að hafa í huga að bæði hárplokk og kropp á húðinni er iðulega rótgróin hegðun og pað getur reynst prautin pyngri fyrir einstakling að hafa stjórn á henni. Pess vegna eru einfaldar ráðleggingar um að reyna að hætta að kroppa eða plokka ekki vænlegar til árangurs og geta jafnvel aukið á vanlíðan og vonbrigði fólks með að geta ekki hamið sig.

Pau lyf sem mest hafa verið rannsökuð í tengslum við meðferð á hárplokkunaráráttu eru SSRI-lyf en illa hefur gengið að sýna fram á árangur peirra. Samanburðarrannsóknir benda til pess að lyfin geri ekki meira gagn en lyfleysa og pær rannsóknir sem hafa sýnt fram á árangur benda til pess að áhrifin séu bara til skamms tíma. Rannsóknir á húokroppunaráráttu eru einnig misvísandi og stærsta rannsóknin sem gerð hefur verið hingð til sýndi engan mun á SSRI og lyfleysu. ${ }^{42}$ Pessar neikvæðu niðurstöður eru athyglisverðar í ljósi pess að kannanir sýna að SSRI-lyfjameðferð er algengasta meðferðin sem fólk pjakað af pessum vandamálum fær. ${ }^{14}$ Pó er vert að hafa í huga að mjög fáar rannsóknir hafa verið gerðar og ekki útilokað að einhver SSRI-lyf geri gagn fyrir að minnsta kosti hluta sjúklinga. Klómipramín hefur sýnt örlítið betri árangur í meðferð hárplokkunaráráttu en hann er pó ekki verulegur og marktækt minni heldur en árangur eftir atferlismeðferð. ${ }^{29}$ Auk pess er langtímaárangur takmarkaður og aukaverkanir pessa lyfs virðast koma illa við fólk með hárplokkunaráráttu. ${ }^{32,} 59$ Annars konar lyfjameðferð hefur einnig borið árangur og eru sérstaklega athyglisverðar niðurstöður á lyfinu N-acetylcystín. Stór samanburðarrannsókn sýndi að N-acetylcystínmeðferð dregur úr hárplokki og sjúklingar pola lyfið vel. ${ }^{36}$ Pá benda tilfellalýsingar til pess að lyfið geri einnig gagn fyrir húðkroppunaráráttu ${ }^{45}$

Rannsóknir hafa oft sýnt að HR er árangursrík leið til að draga úr bæði hárplokkunar- og húðkroppunaráráttu og meðferðin virðist gera meira gagn en pau lyf sem í boði eru. Pó er algengt að fólk hrasi eftir HR, sérstaklega ef pað nær ekki fullum bata í meðferðinni. Pví er mikilvægt er að rannsaka hvers vegna meðferðin virkar og próa hana enn frekar. Einnig er brýnt að fá úr pví skorið hvort og að hve miklu leyti annars konar sálfræðimeðferð (til dæmis ACT eða hugræn meðferð) dregur úr pessum vandamálum eða bætir við árangur HR. Hárplokkunar- og húðkroppunarárátta eru lítið pekkt og lítið rannsökuð vandamál. Miðað við pær rannsóknir sem liggja fyrir má mæla með HR sem fyrsta kosti í meðferð. pví miður eru afar fáir meðferðaraðilar sem kunna að beita meðferðinni en hún er tiltölulega einföld í framkvæmd, sérstaklega fyrir pá sem pekkja atferlissálfræði. 


\section{Heimildir}

1. Laxness HK. Brekkukotsannáll. Helgafell, Reykjavík 1957.

2. Stein DJ, Grant JE, Franklin ME, Keuthen N, Lochner C, Singer HS, et al. Trichotillomania (hair pulling disorder), skin picking disorder, and stereotypic movement disorder: Toward DSM-V. Depress Anxiety 2010; 27: 611-26.

3. Snorrason I, Belleau EL, Woods DW. Hair pulling disorder (trichotillomania) and skin picking disorder: A review of evidence for comorbidity, similarities and shared etiology. Óbirt gögn.

4. Snorrason Î. Húðkroppunarárátta: Klínísk einkenni, tengs við aðrar geðraskanir og flokkun í DSM. Sálfræðiritið 2008; 13: 9-26.

5. Snorrason Í, Smári J, Ólafsson RP. Húđkroppunarárátta: Klínísk einkenni og tengsl viơ geðræn vandamál í úrtaki háskólanema. Sálfræðiritið 2009; 14: 103-13.

6. Snorrason I, Smári J, Ólafsson RP. Emotion regulation in pathological skin picking: Findings from a non-treatment seeking sample. J Behav Ther Exp Psychiatry 2010; 41: 23845.

7. Snorrason I, Smári J, Ólafsson RP. Motor inhibition reflection impulsivity and trait impulsivity in pathological skin picking. Behav Ther 2011; 42: 521-32.

8. Cristenson GA, Pyle RL, Mitchell JE. Estimated lifetime prevalence of trichotillomania in college students. J Clin Psychiatry 1991; 52: 415-7.

9. Grant JE, Williams KA, Potenza MN. Impulse-control disorders in adolescent psychiatric inpatients: Co-occurring disorders and sex differences. J Clin Psychiatry 2007; 68: 1584-92.

10. Bohne A, Wilhelm S, Keuthen NJ, Bear L, Jenike MA. Skin picking in German students. Behav Modif 2002; 20: 320-9.

11. Keuthen NJ, Koran LM, Aboujaoude E, Large MD, Serpe RT. The prevalence of pathologic skin picking in US adults. Compr Psychiatry 2010; 51: 183-6.

12. Griesemer RD. Emotionally triggered disease in a dermatologic practice Psychiatr Ann 1978; 8: 407-12.

13. Snorrason I. Tíðni húðkroppunaráráttu meðal íslenskra háskóla- og menntaskólanema. Óbirt gögn.

14. Marcks BA, Wetterneck CT, Woods DW. Investigating healthcare providers' knowledge of trichotillomania and its treatment. Cognit Behav Ther 2006; 35: 19-27.

15. Szepietowski JC, Salomon J, Pacan P, Herehorów E, Zalewska A. Frequency and treatment of trichotillomania in Poland. Acta Derm Venereol 2009; 89: 267-70.

16. Woods DW, Flessner CA, Franklin ME, Keuthen NJ Goodwin RD, Stein DJ, et al. The Trichotillomania Impact Project (TIP): exploring phenomenology, functional impairment, and treatment utilization. J Clin Psychiatry 2006; 67: 1877-88.

17. American Psychiatric Association. Diagnostic and Statistical Manual of Mental Disorders ( $4^{\text {th }}$ edition, text revision). American Psychiatric Association, Washington, DC 2000.

18. Tay Y, Levy ML, Metry D W. Trichotillomania in childhood: Case series and review. Pediatrics 2004; 113, 494-8.

19. Flessner CA, Conelea CA, Woods DW, Franklin ME, Keuthen NJ, Cashin SE. Styles of pulling in trichotillomania: Exploring differences in symptom severity, phenomenology, and functional impact. Behav Res Ther 2008; 46: 345-57.

20. Walther MR, Flessner CA, Conelea CA, Woods DW. The Milwaukee Inventory for the Dimensions of Adult Skin Picking (MIDAS): initial development and psychometric properties. J Behav Ther Exp Psychiatry 2009; 40: 127-35.

21. Sah DE, Koo J, Price WH. Trichotillomania. Dermatologic Therapy 2008; 21: 13-21.

22. Arnold LM, McElroy SL, Mutasim DF, Dwight MM, Lamerson CL, Morris EM. Characteristics of 34 adults with psychogenic excoriation. J Clin Psychiatry 1998; 59: 509-14.
23. Diefenbach GJ, Tolin DF, Meunier S, Worhinsky P. Emotion regulation and trichotillomania: A comparison of clinical and nonclinical hair pulling. J Behav Ther and Exp Psychiatry 2008; 39: 32-41.

24. Wilhelm S, Keuthen NJ, Deckersbach T, Engelhard IM, Forker AE, Baer L, et al. Self-injurious skin picking: clinical characteristics and comorbidity. J Clin Psychiatry 1999; 60: 454-9.

25. Christenson GA, Mackenzie TB, Mitchell JE, Callies AL. A placebo-controlled, double blind crossover study of fluoxetine in trichotillomania. Am J Psychiatry 1991; 148: 1566-71.

26. Streichenwein SM, Thornby JI. A long-term, doubleblind, placebo-controlled crossover trial of the efficacy of fluoxetine for trichotillomania. Am J Psychiatry 1995; 152: $1192-6$.

27. van Minnen A, Hoogduin KAL, Keijsers GPJ, Hellenbrand I, Hendriks G-J. Treatment of trichotillomania with behavior therapy or fluoxetine. Arch Gen Psychiatry 2003; 60: 517-22.

28. Dougherty DD, Loh R, Jenike MA, Keuthen NJ. Single modality versus dual modality treatment of trichotillomania: Sertraline, behavior therapy or both? J Clin Psychiatry 2006; 67: 1087-96.

29. Bloch $\mathrm{MH}$, Landeros-Weisenberg A, Dombrowski $\mathrm{P}$, Kelmendi B, Wegner R, Nudel J, et al. Systematic review: pharmacological and behavioral treatment for trichotillomania. Biol Psychiatry 2007; 62: 839-46.

30. Iancu I, Weizman A, Kindler S, Sasson Y, Zohar J. Serotonergic drugs in trichotillomania: treatment results in 12 patients. J Nerv Ment Dis 1996; 184: 641-4.

31. Swedo SE, Leonard HL, Rapoport JL, Lenane MC, Golberger EL, Cheslow DL. A double-blind comparison of clomipramine and desipramine in the treatment of trichotillomania (hair pulling). N Engl J Med 1989; 321: 497-501.

32. Ninan PT, Rothbaum BO, Marsteller FA, Knight BT, Eccard MB. A placebo-controlled trial of cognitivebehavioral therapy and clomipramine in trichotillomania.J Clin Psychiatry 2000; 61: 47-50.

33. Swedo SE, Lenane MC, Leonard HL. Long term treatment of trichotillomania (hair pulling). N Engl J Med 1993; 329: 141-2.

34. Ninan PT, Knight B, Kirk L, Rothbaum BO, Kelsy J, Nemeroff CB. A controlled trial of venlafaxine in trichotillomania: interim phase I results. Psychopharmacol Bull 1998; 34: 221-4.

35. Ninan PT. Conceptual issues in trichotillomania, a prototypical impulse control disorder. Curr Psychiatry Rep 2000; 2: 72-5.

36. Grant JE, Odlaug BL, Kim SW. N-Acetylcysteine, a glutamate modulator, in the treatment of trichotillomania: A double-blind, placebo-controlled study. Arch Gen Psychiatry 2009; 66: 756-63.

37. van Ameringen M, Mancini C, Patterson B, Bennett M, Oakman J. A randomized, double-blind, placebo-controlled trial of olanzapine in the treatment of trichotillomania. J Clin Psychiatry 2010; 71: 1336-43.

38. Stewart RS, Nejtek VA. An open-label, flexible-does study of olanzapine in the treatment of trichotillomania. J Clin Psychiatry 2003; 64: 49-52.

39. Khouzam HR, Battista MA, Byers PE. A case study: An overview of trichotillomania and its response to treatment with quetiapine. Psychiatry 2002; 65: 261-70.

40. Bloch MR, Elliot M, Thompson H, Koran LM. Fluoxetine in pathological skin picking: Oben-label and double-blind results. Psychosom 2001; 42: 314-9.

41. Simeon D, Stein DJ, Gross S, Islam N, Schmeidler J, Hollander E. A double-blind trial of fluoxetine in pathological skin picking. J Clin Psychiatry 1997; 58: 341-7.
42. Arbabi M, Farnia V, Balighi K, Mohammadi MR, NejatiSafa AA, Yazdchi K, et al. Efficacy of citalopram in treatment of pathological skin picking, a randomized double blind placebo controlled trial. Acta Medica Iranica 2008; 46: 367-72.

43. Grant JE, Odlaug BL, Kim SW. Lamotrigine treatment of pathological skin picking: An open-label study. J Clin Psychiatry 2007; 68: 1384-91.

44. Grant JE, Odlaug BL, Chamberlain SR, Kim SW. A double-blind, placebo-controlled trial of Lamotrigine for pathological skin picking: Treatment efficacy and neurocognitive predictors of response. J Clin Psychopharmacol 2010; 30: 396-403.

45. Odlaug BL, Grant JE. N-acetyl cysteine in the treatment of grooming disorders. J Clin Psychopharmacol 2007; 27: $227-9$.

46. Grant JE, Odlaug BL. Update on pathological skin picking. Curr Psychiatry Rep 2009; 11: 283-8.

47. Azrin NH, Nunn RG. Habit-reversal: Method of eliminating nervous habits and tics. Behaviour Res Ther 1973; 11: 619-28.

48. Mansueto CS, Golomb RG, Thomas AM, Stemberger RMT. A comprehensive model for behavioral treatment of trichotillomania. Cognit Behav Practice 1999; 6: 23-43.

49. Keuthen NI, Rothbaum BO, Welch SS, Taylor C, Falkenstein M, Heekin M, et al. Pilot trial of dialectical behavior therapy-enhanced habit reversal for trichotillomania. Depress Anxiety 2010; 27: 953-9.

50. Hayes SC, Strosahl KD, Wilson KG. Acceptance and commitment therapy: An experiential approach to behavior change. Guilford Press, New York 2003.

51. Woods DW, Wetterneck CT, Flessner CA. A controlled evaluation of acceptance and commitment therapy plus habit reversal for trichotillomania. Behav Res Ther 2006; 44: 639-56.

52. Azrin NH, Nunn RG, Frantz SE. Treatment of hair pulling (trichotillomania): A coparative study of habit reversal and negative practice training. J Behav Ther Exp Psychiatry 1980; 11: 13-20.

53. Diefenbach GJ, Tolin DF, Hannan S, Maltby N, Crocetto J. Group treatment for trichotillomania: Behavior therapy versus supportive therapy. Behav Ther 2006; 37: 353-63.

54. Keijsers GP, van Minnen A, Hoogduin CA, Klaassen BN, Hendriks MJ, Tanis-Jacobs J. Behavioural treatment of trichotillomania: two-year follow-up results. Behav Res Ther 2006; 44: 359-70.

55. Teng EJ, Woods DW, Twohig MP. Habit reversal as a treatment for chronic skin picking - A pilot investigation. Behav Modif 2006; 30: 411-22.

56. Schuck K, Keijsers GPJ, Rinck M. The effects of brief cognitive-behaviour therapy for pathological skin picking: a randomized comparison to wait-list control. Behav Res Ther 2011; 49: 11-7.

57. Deckersbach T, Wilhelm S, Keuthen NJ, Baer L, Jenike MA. Cognitive-behavior therapy for self-injurious $\mathrm{w}$ picking. Behav Modif 2002; 26: 361-77.

58. Twohig MP, Hayes SC, Masuda A. A preliminary investigation of acceptance and commitment therapy as a treatment for chronic skin picking. Behav Res Ther 2006; 44: 1513-22.

59. Denys D, van Megen HJGM, Westenberg HGM. Emerging skin-picking behaviour after serotonin reuptake inhibitortreatment in patients with obsessive-compulsive disorder: Possible mechanisms and implications for clinical care. J Psychopharmacol 2003; 17: 127-9. 


\section{ENGLISH SUMMARY}

\section{Diagnosis and treatment of hair pulling- and skin picking disorder}

Snorrason I, ${ }^{1}$ Björgvinsson $\mathrm{T}^{2}$

Hair pulling disorder (HPD; trichotillomania) is characterized by recurrent pulling of hair from the scalp, eyebrows or other parts of the body. Skin picking disorder (SPD) is closely related to HPD and involves recurrent picking of the skin. Even though both HPD and SPD are relatively common and potentially severe disorders, health professionals typically know little about them. In the present article, we describe the clinical characteristics of these problems and provide diagnos-

tic guidelines. We also discuss main treatment approaches (drug treatments and behavior therapy) and review research on their efficacy. Results show that behavior therapy (habit reversal) has consistently been shown to be effective, SSRIs seem not to work, but preliminary data suggest that other drugs (e.g. N-Acetylcysteine) may benefit some patients.

Key words: Trichotillomania, hair pulling, skin picking, drug treatment, behavioral treatment.

Correspondence: Ívar Snorrason, ivarsnorrason@gmail.com

${ }^{1}$ Department of Psychology University of Wisconsin-Milwaukee, ${ }^{2}$ McLean Hospital / Harvard Medical School. 